\title{
Discussion and Analysis of New Higher Vocational Education in Independent College under New Situation of Globalization and Informatization
}

\author{
Dong Zhang, Jiang-ming Kuang \\ The Engineering \& Technical College of Chengdu University of Technology, Leshan, Sichuan, China, 999078 \\ zd7585@qq.com
}

\begin{abstract}
The independent college is a new type of university undergraduate course education mechanism under the condition that talent supply \& demand cannot match severely. The purpose of this mechanism is to cultivate applied talents for national demand and provide talent guarantee for national modernization construction. With the development of globalization and information technology, previous education models have not meet social needs, so this caused imbalance of supply and demand at present. In order to change this situation, in this paper, the current situation of independent college, globalization, information technology and the current education system, are particularly summarized, presenting the talent training mode of independent colleges under the new situation and expecting solution to the existing condition.
\end{abstract}

keyword-Globalization, informatization, independent college, vocational education;

\section{INTRODUCTION}

The independent college refers to the higher education colleges with the bachelor degree education qualification, which are established by means of non-state financial fund by the general institutes of higher education with the bachelor degree education and above cooperating with social organizations and individuals except state institutions. The independent college education is an important component in the higher education system of our country, and they are non-governmental colleges with Chinese characteristics, in which students are charged as per the cost. This education mode increase the undergraduate enrollment scale in colleges and universities, in addition, for talent cultivation, make the original mode from "cultivation" to "market" changed to "demand" to "cultivation", and then to "market". Such a talent cultivation mode can not only change the unmatched problem from "cultivation" to "demand", but also greatly reduce education resource waste, lower the unemployment rate of the graduate and improve the production rate of enterprises.

Independent colleges experienced three periods from establishment to now, namely attachment period, independent period and development period.

\section{GLOBALIZATION}

\section{A. Development History}

Globalization can date back to 1492 when Columbus discovered the new continent. In that year Columbus sailed to America to make residents of the eastern and the western hemispheres know each other. Since then, human communication became more and more frequent in all aspects, and their contact became closer and closer, of course, including the fierce conflict and even war, and the gradually formed world market. However, their association at that time was summarized by Marx with the saying "Interaction and interdependence of all nationalities in all aspects", and the first 50 years' history is briefly summarized as "international era".

Only in 1992 after five hundred years, people felt that there is a global power threatening each country, each region, each nationality, each group, and countless individuals enter into a surging megatrend.

\section{B. Prominent Mark of Globalization Tendency}

A prominent mark forming the feel is collapse of the Eastern Europe Warsaw group at the end of 1989 and soviet disintegration after two years. An almost strongest power in military might, industry, science \& technology collapsed suddenly in just dozens of days, without any invasion of foreign enemies; this is a thing never seen in human history, and what is the unusual force? Now we cannot make a precise analysis to explain the reason, but a few points may be put forward for discussion as reason analysis:

I) The power of market-oriented economy shatters an ignescent system;

2) Information spreading broke through a closed system;

3) Too high transaction expenses gave rise to system selection;

4) Second law of thermodynamics in the system theory states that opening is essential to continual development of the system, a closed system without any information exchange with the external world is sure to die out. 
5) Of course, the most fundamental reason is that they are defeated at the peaceful economic competition with the western capitalist countries, and cannot create higher productivity than capitalism.

\section{INFORMATIZATION}

The information technology refers to normalization of the national economy and the society. Its meaning is to entirely develop and generally use modern information technologies in all departments of national economy and all fields of social activities, develop and utilize all kinds of information resources fully and effectively, so as to make the proportion of created labor value (added information economics) in the gross national product gradually rise until it predominates, and make all social departments and all the people can enjoy and transmit information each other through various information media (audio, digital, image and video) whenever and wherever, and to improve government at all levels macroeconomic regulation \& control and decision-making ability of the government at all levels, improve learning and working efficiency of every organization and individual and the innovation ability, promote the development of social productive forces, raise people's cultural education level and the comprehensive quality and the quality of life, enhance the comprehensive national strength and international competitiveness, make social material civilization and spiritual civilization effectively developed. Normalization is both a challenge and an opportunity for us; it is an urgent task needed to be urgently implemented and a long endless process.

Content elements of normalization

1) Information infrastructure.

It is integrated with the information transmission network, the information processing software and hardware equipment, information resource library. This is the supporting environment of normalization.

2) Information industry.

It includes the hardware manufacturing industry, software industry and information service industry. This is the pillar of normalization.

3) Information technology.

It includes research, development and application technology. This is the foundation of normalization.

4) Information talented persons, including various talent teams and team spirit. This is the motility of normalization.

5) Information environment.

It includes standardization, security, intellectual property rights, policies and regulations and moral rule. This is guarantee for orderly operation of informationization. All elements correlate with each other and rely on each other, which forms the overall social informationization.

\section{SUMMARY OF INDEPENDENT COLLEGE'S EDUCATION} PATTERN

Teaching syllabus and teaching requirements of independent colleges frequently follow the teaching model of ordinary universities for talents cultivation. On the one hand, this causes its graduates after graduation are deficient in competition with graduates of the normal universities; On the other hand, because its teaching mode is based mainly on theory, this causes its graduates differ from graduates of higher vocational colleges in application skills. In addition, the students of the independent colleges have a weak foundation and poor self-learning ability, so this causes unsatisfactory employment. In order to solve the low graduate employment rate of the independent colleges, it is necessary to try to change the teaching mode accordingly. Therefore, independent colleges should implement teaching mode reform from the point of view of improving the students' skill and training applied talents.

1. Solid theoretical foundation;

2. Improve the student s practice ability;

3. Strengthen self learning ability.

\section{CONTRADICTION BETWEEN INPUT AND OUTPUT}

Talent problem has always puzzled the development of enterprises and institutions in our country. On the one hand, the employers have urgent need of talents; on the other hand, there are millions of job seekers have no job. Many people make every endeavor to seek the solution. Moreover, as the number of college graduates has increased year by year, this contradiction will be more highlighted, and problems will be more and more striking. For such a huge demand for talents, why there are a lot of graduates who cannot find jobs? The key to the problem is:

On the one hand, universities blindly follow suit to recruit students. As market selection changes, there are many blind followers in college enrollment. If graduates in the accounting major can get jobs easily this year, so in next year and even the next few years more students will be enrolled in the accounting major. If graduates from the IOT (internet of things) major can take up an occupation easily next year, then a large number of students will be enrolled in the major. Universities with the major recruit students, and universities without the major, endeavor to increase the amount of students in this major. Everyone wants to take a share of the spoils, they hardly realize that the market becomes saturated eventually, as time goes on, previously dominant majors will become the majors with a large number of graduates difficult to get jobs.

On the other hand, enterprises need experienced and skilled graduates and hope they can bring direct economic benefits to their companies. However, in fact, it is almost impossible for newly graduated college graduates to have work experience. Most they contacted is contents teaching books show, so they almost have no practical experience, this has brought great obstacles to student employment. Such result is that enterprise and public institutions can't find talents they want, and students can't find satisfaction jobs. From the point of contradictory relations, shortage of talents is only relatively insufficient; in fact there are a large number of unemployed college 
graduates. The situation must be changed by reforming the current education system, especially the education system independent colleges is more urgent to be changed, because their survival depends on student enrollment.

\section{TEACHING MODE IN NEW PATTERN}

Our country is carrying out the school development pattern of "industry-university-research". This method is used to effectively drive to scientific research findings of universities to the market and complete industrialization of achievements. Why can't talent cultivation come from the market and go to the market? The cultivation goals of innovation education should be achieved through the course system and the teaching mode. In the design link of the teaching mode, students should be guided to establish four base points, i.e. basic education, quality education and ability education and innovation education, to realize the four transformation, namely, from passive learning to active learning, from specialist training to the training of versatile learners, from course teaching to ability education and from imitation practice to innovation practice.

(一) Building a new teaching content system and strengthening ability training. At present, the development trend of science and technology is high differentiation and integration between disciplines, mutual penetration, influence, interaction and restriction between disciplines become a remarkable feature of the development of science and technology today. Therefore, the targeted, applied and cutting-edge teaching content system must be established to meet the demand of applied talents' cultivation. Firstly, the coverage of teaching content should be broadened to make students form a comprehensive teaching content system with intersection and permeation between natural science and humanities and close combination of various disciplines. Secondly, we must update teaching content. The teaching content must keep pace with the times. The latest educational reform achievements, the latest developments of academic frontiers and the latest frontier trend in the world should timely be added in the teaching content to make the students able to absorb fresh "nutrient" as soon as possible.

(二) Innovation education is the core of quality education, and cultivation of creative ability is the core of the classroom teaching and its highest requirement. No matter which course is learned, it will ultimately come down to the solution to a certain class of problems; but creation is the highest form of problem solving, therefore creativity training should become a major goal of the class.

In the process of developing the innovative ability of college students, the teacher plays a leading role. How can university teachers cultivate and stimulate students' creative potential in the classroom teaching? Teachers must focus on cultivating students' innovation ability in the classroom teaching activities and building an innovation environment. The research-oriented teaching mode should be used to guide students to explore actively.
The research-based teaching is the teaching method emphasizing forming process of the scientific principle. It stresses that the presentation mode of teaching content should be process-oriented. Teachers should demonstrate resulting causes and research process of subject concept and basic principle to students, so as to let the students make an all-round and multi-angle thought and stimulates the student's enthusiasm and initiative in self-learning and exploration, and enhance students' creativity and consciousness in participating in the knowledge construction. In the research-oriented teaching mode, teachers become mentors from the knowledge transmitters, and students become the active builder of knowledge from the passive receiver of knowledge. University classroom teaching should be heuristic rather than indoctrinating teaching; it is directive rather than moralizing teaching; it is communicative rather than closed teaching and it is the discussion \& analysis mode instead of the hidebound changeless teaching. In addition, some research-oriented and exploratory tasks or questions may be arranged in order to make them think and explore actively. An equal, harmonious, and democratic classroom atmosphere should be created. It is necessary to believe student's knowledge and ability and to encourage students to boldly put forward their own opinions and views, especially the different opinions and views against teacher and to let them draw the correct conclusion by discussion and research analysis. The extreme student should be specially guided with equal debate so as to convince them by reasoning. Only in this way we can actually understand the degree of student's mastering knowledge and test the teaching effect, so as to enhance students' self-confidence and make student dare to express their points of view, and make them release their maximum innovation potential.

(三) With a task as the drive, a new teaching model "task-driven method" is explored based on the constructivism theory, it is an inquiry-based teaching method with student as the center and a task as the drive. Its basic principle is: the teachers design targeted, strongly practical, goal-oriented knowledge points as a task, and contain the taught knowledge and skills in the task, so that the students can master the knowledge and application skills during completing the task independently. The basic process is: offering the task, task analysis, students' operation, communication and discussion, consolidating innovation and summary. Its remarkable performance is: the teachers' teaching and students' learning are pointing to a goal; driven by the strong problem motivation, students can carry out independent exploration and interactive collaborative learning through active use of learning resources; upon completion of the task, a new task is produced at the same time. Its significant advantage is to effectively cultivate students' comprehensive ability to use knowledge to solve practical problems.

\section{CONCLUSION}

The independent college is a new type of university undergraduate course education mechanism under the 
condition that talent supply \& demand cannot match severely, which are established by means of non-state financial fund by the general institutes of higher education with the bachelor degree education and above cooperating with social organizations and individuals except state institutions. Its aim is to cultivate applied talents for national demand and provide talent guarantee for national modernization construction. However, with the development of globalization and information technology, previous education models have not meet social needs, so this caused imbalance of supply and demand nowadays. In order to change this situation, the current situation of independent college, globalization, information technology and the current education system are analyzed in this paper, and the talent training mode of independent colleges under the new situation is proposed so as to expect that the existing condition will be solved. It is of guiding significance to the future teaching mode of the independent colleges.

\section{REFERENCE}

[1] V. Cable, 23 April 2014, 830,000 new engineers over the next 8 years.https://www.gov.uk/government/speeches/where-next-for-fu rther-andhigher-education

[2] V. Cable, 23 April 2014, 830,000 new engineers over the next 8 years.https://www.gov.uk/government/speeches/where-next-for-fu rther-andhigher-education

[3] T. Hunt, Speech to ASCL Conference, http://www.ascl.org.uk/ download.922B44BF-326F-483A-AE484FE5F0BB4F2B.html

[4] J.M. Davies and D. Hough, 17 December 2014, Youth Unemployment 